\title{
Synthetic innate defense regulator peptide combination using CpG ODN as a novel adjuvant induces long-lasting and balanced immune responses
}

\author{
CHAO-HENG YU ${ }^{1 *}$, ZI-CHAO LUO ${ }^{2 *}$, MENG LI $^{1}$, LIAN LU ${ }^{1}$, ZHAN LI $^{1}$, XIAO-ZHE WU ${ }^{1}$, \\ YING-ZI FAN ${ }^{1}$, HAI-LONG ZHANG ${ }^{1}$, BAI-LING ZHOU ${ }^{1}$, YANG WAN ${ }^{1}$, KE MEN $^{1}$, \\ YAO-MEI TIAN $^{1}$, SHUANG CHEN ${ }^{1}$, FENG-JIAO YUAN ${ }^{1}$, RONG XIANG $^{3}$ and LI YANG $^{1}$ \\ ${ }^{1}$ State Key Laboratory of Biotherapy/Collaborative Innovation Center for Biotherapy,
}

West China Hospital, Sichuan University, Chengdu, Sichuan 610041; ${ }^{2}$ Institute of Biomedical Engineering, School of Ophthalmology \& Optometry and Eye Hospital, Wenzhou Medical College, Wenzhou, Zhejiang 325000;

${ }^{3}$ Department of Immunology, Nankai University School of Medicine, Nankai, Tianjin 300071, P.R. China

Received December 25, 2014; Accepted September 22, 2015

DOI: $10.3892 / \mathrm{mmr} .2015 .4581$

\begin{abstract}
Vaccines are critical tools for the prevention and treatment of several diseases. Adjuvants have been traditionally used to enhance immunity to vaccines and experimental antigens. In the present study, the adjuvant combination of $\mathrm{CpG}$ oligodeoxynucleotides (CpG ODN) and the innate defense regulator (IDR) peptide, IDR- $\mathrm{HH}_{2}$, was evaluated for its ability to enhance and modulate the immune response when formulated with alum and the recombinant hepatitis B surface antigen (HBsAg). The CpG-HH2 complex enhanced the secretions of tumor necrosis factor- $\alpha$, monocyte chemotactic protein 1 and interferon $\gamma$ by human peripheral blood mononuclear cells and promoted murine bone marrow dentritic cell maturation. In addition, the present study demonstrated that IDR-HH2 was chemotactic for human neutrophils, THP-1 cells and RAW264.7 cells at concentrations between 2.5 and $40 \mu \mathrm{g} / \mathrm{ml}$. The present study also observed that significantly higher anti-HBs antibody titers, which were sustained at high levels for as long as 35 weeks following the boost immunization, were induced by the combination adjuvant, even when co-administered with a commercial hepatitis $\mathrm{B}$ vaccine at a low antigen dose $(0.1 \mu \mathrm{g}$ HBsAg). Notably, the level of IgG2a was almost equal to the level of IgG1, indicating that a balanced T helper (Th)1/Th2 immune response was elicited by the novel
\end{abstract}

Correspondence to: Professor Li Yang, State Key Laboratory of Biotherapy/Collaborative Innovation Center for Biotherapy, West China Hospital, Sichuan University, 4 Keyuan Road, Gaopeng Street, Chengdu, Sichuan 610041, P.R. China

E-mail: yl.tracy73@gmail.com

*Contributed equally

Key words: hepatitis B virus, adjuvant, CpG oligodeoxynucleotides, innate defence regulator-HH2, balanced immune responses vaccine, which was consistent with the ELISpot results. These data suggest that the $\mathrm{CpG}-\mathrm{HH} 2$ complex may be a potential effective adjuvant, which facilitates a reduction in the dose of antigen and induces long-lasting, balanced immune responses.

\section{Introduction}

Adjuvants have been demonstrated to be key components in vaccines and are capable of enhancing and/or shaping antigen-specific immune responses (1). The majority of the existing vaccines include a signal adjuvant, however, single adjuvants may be limited to inducing immune responses of low potency or quality, therefore, single adjuvants cannot elicit the optimal immune responses required for certain vaccines (2). Thus, the combined co-administration of different adjuvants with antigens is a potential approach for improving immune responses to vaccines. In previous years, numerous combination adjuvants have been investigated, including alum and CpG oligodeoxynucleotides (ODN), CpG ODN and polyphosphazenes, and CpG ODN and LL-37, which demonstrate a synergistic response following vaccine immunization $(2,3)$. Furthermore, the combination adjuvant, CpG-host defense peptide (HDP), has been demonstrated to exhibit a synergistic immune response in mice when co-injected with ovalbumin and leads to an improvement of innate immune in newborn piglets $(4,5)$. In the present study, $\mathrm{CpG}$ ODN was combined with innate defense regulator (IDR) peptide, IDR-HH2, as a novel adjuvant to evaluate its ability to enhance and modulate the immune response when formulated with commercial hepatitis B (HBV) vaccines, consisting of hepatitis B surface antigen (HBsAg) and alum, which typically induce a $\mathrm{T}$ helper (Th)2-type immune response (6).

IDRs are synthetic mimics of host defense peptides, which are important components of the innate immune system and have well-documented selective immune stimulatory activities (7). IDRs have also been reported to induce the production of cytokines/chemokines by immune cells, stimulate angiogenesis and wound healing, and modulate monocyte-macrophage 
differentiation and monocyte-dendritic cell differentiation (8). Our previous studies focused on the antimicrobial and adjuvant activity of IDRs, designed a novel IDR-DP7 and developed a combination adjuvant for tumor vaccine $(9,10)$. $\mathrm{HH} 2$ is a synthetic 12-aa IDR optimized for immunomodulatory activity, which can form a complex with $\mathrm{CpG}$ ODN via electrostatic interactions and stimulate potent antibody production and B cell expansion (11). In addition, IDR-HH2 has been demonstrated to recruit neutrophils (12).

CpG ODNs containing unmethylated $\mathrm{CpG}$ motifs have been confirmed as potent stimulants of $\mathrm{B}$ cells and plasmacytoid dendritic cells (13). They are recognized by Toll-like receptor 9 , and induce the proliferation of the majority of $B$ cells and the secretion of immunoglobulin (Ig) and cytokines $(14,15)$. CpG ODNs also directly activate a number of other types of immune cells, including monocytes, macrophages and dendritic cells, resulting in the secretion of pro-inflammatory interleukin (IL)-1, IL-6, IL-18 and tumor necrosis factor (TNF)- $\alpha$, and IL-12 and interferon (IFN)- $\gamma$ type 1 cytokines (16). Previous studies have demonstrated that when co-administered with several viral and bacterial antigens, $\mathrm{CpG}$ ODNs elicit enhanced immune responses and overcome the type 2 bias associated with conventional adjuvants, including alum or oil-based adjuvants (17-19).

To date, the use of the CpG-HH2 complex as an adjuvant of HBV vaccines has not been reported. The aim of the present study was to investigate whether the $\mathrm{CpG}-\mathrm{HH} 2$ complex is able to overcome the Th2 immune response induced by alum when co-administered with a commercial HBV vaccine, and induce mixed Th1/Th2 responses. The resultant novel HBV vaccine may trigger more potent and effective protection against the pathogen and indicate that the $\mathrm{CpG}-\mathrm{HH} 2$ complex may be used as a potential adjuvant formulation.

\section{Materials and methods}

Materials. Phosphorothioate-stabilized CpG ODN (5'-TCG TCGTTTTGTCGTTTTGTCGTT-3') was synthesized by Invitrogen (Thermo Fisher Scientific, Inc., Waltham, MA, USA). IDR-HH2 (VQLRIRVAVIRA-NH2), the major histocompatibility complex (MHC) class I-restricted $\mathrm{HBsAg}_{208-216}$ peptide (ILSPFLPL) and MHC class II restricted HBsAg ${ }_{126-138}$ peptide (RGLYFPAGGSSSG) were synthesized by Shang Hai Science Peptide Biological Technology Co., Ltd (Shanghai, China). Aluminum hydroxide (alum) was purchased from Brenntag Biosector (Frederikssund, Denmark). HBsAg was purchased from American Research Products, Inc. (Waltham, MA, USA).

Cell preparation and chemotaxis assay. Neutrophils were prepared by density gradient centrifugation using Polymorphprep ${ }^{\mathrm{TM}}$ (Axis-Shield Poc As, Oslo, Norway), according to the manufacturer's protocol. Briefly, venous blood $(20 \mathrm{ml})$ was collected from 3 healthy volunteers $(2$ male, 1 female; aged 23-35), who had provided informed consent, at the West China Hospital (Chengdu, China). The blood was layered onto an equal volume of Polymorphprep, followed by centrifugation at $500 \mathrm{x} \mathrm{g}$ for 30-35 $\mathrm{min}$ at room temperature. The plasma and mononuclear cells were removed, and the lower band of polymorphonuclear neutrophils were collected and washed twice in RPMI 1640 medium (Gibco; Thermo Fisher Scientific, Inc.). The neutrophils were resuspended in RPMI 1640 with $10 \%$ FBS (Gibco; Thermo Fisher Scientific, Inc.) at a concentration of $1 \times 10^{7}$ cells $/ \mathrm{ml}$ for the chemotaxis assay.

The chemotactic activities of THP-1 monocytes (American Type Culture Collection, Rockville, MD, USA) and RAW264.7 cells (Type Culture Collection of the Chinese Academy of Sciences, Shanghai, China) in response to IDR-HH2 were measured in a 24-well Transwell plate (Nunc ${ }^{\circledR}$; Thermo Fisher Scientific, Inc.) with a $8.0-\mu \mathrm{m}$ pore size polycarbonate membrane. The neutrophils were assayed in a 24-well Transwell plate (Corning Incorporated, Corning, NY, USA) with a $3.0-\mu \mathrm{m}$ pore size polycarbonate membrane. THP-1 cells were suspended in RPMI 1640 with $10 \%$ FBS, while RAW264.7 cells were suspended in Dulbecco's modified Eagle's medium (Gibco; Thermo Fisher Scientific, Inc.) with $10 \%$ FBS. Subsequently, $100 \mu 1$ aliquots of the cell suspensions at concentrations of $2 \times 10^{6}$ cells $/ \mathrm{ml}$ (THP- 1$), 5 \times 10^{6}$ cells $/ \mathrm{ml}$ (RAW264.7), $1 \times 10^{7}$ cells $/ \mathrm{ml}$ (neutrophils) were added into separate Transwell inserts of the chemotaxis chambers, in which the lower compartment contained $600 \mu \mathrm{l}$ of media containing IDR-HH2 $(0,2.5,5,10,20$ or $40 \mu \mathrm{g} / \mathrm{ml})$. Following incubation at $37^{\circ} \mathrm{C}$ for 45,90 and $180 \mathrm{~min}$, the inserts were removed, and the THP-1 cells, which had migrated into the lower chamber, were scored using fluorescence-activated cell sorting analysis within $2 \mathrm{~min}$, whereas the chemotactic migration of the two other types of cell, which were stained with $0.01 \%$ crystal violet (Beyotime Institute of Biotechnology, Shanghai, China), was determined by counting the number of migrated cells on the polycarbonate membrane in five randomly selected microscope fields per well (magnification, $x 400$ ). The results were expressed as the number of migrated cells in response to IDR-HH2.

Isolation of bone marrow dendritic cells (BMDCs). The experimental protocol was approved by the Ethics Review Committee for Animal Experimentation of Sichuan University. Female C57BL/6J mice (6-8 weeks old) were purchased from the Experimental Animal Center of Sichuan University (Sichuan, China) and maintained at $23 \pm 1^{\circ} \mathrm{C}$ in a 12-h light/dark cycle with free access to food and water in a pathogen-free animal facility. Mice were sacrificed by cervical dislocation, and the femur and tibia were removed. The ends of the femur and tibia were pierced using a $1 \mathrm{ml}$ syringe, and the bone marrow washed 5 times with RPMI 1640. The BMDCs were collected and centrifuged at $300 \mathrm{x}$ g for $3 \mathrm{~min}$ at room temperature, washed twice with RPMI 1640, followed by incubation with red blood cell lysis buffer (Beyotime Institute of Biotechnology) for 3-5 min at room temperature. Following two washes, the cells were suspended in RPMI 1640 with $10 \%$ heat-inactivated $\mathrm{FBS}$, and cultured at $37^{\circ} \mathrm{C}$ in $5 \% \mathrm{CO}_{2}$ for subsequent experiments.

Flow cytometeric analysis. BMDCs were cultured for 5 days in RPMI 1640 complete medium supplemented with $10 \mathrm{ng} / \mathrm{ml}$ each of granulocyte-macrophage colony-stimulating factor and IL-4 (Shanghai PrimeGene Bio-Tech, Shanghai, China). The BMDCs $\left(2 \times 10^{6}\right.$ cells $\left./ \mathrm{ml}\right)$ were incubated with either $\mathrm{CpG}$ ODN, IDR-HH2, the CpG-HH2 complex or lipopolysaccharide (LPS; Sigma-Aldrich, St. Louis, MO, 
USA) for $16 \mathrm{~h}$ at $37^{\circ} \mathrm{C}$ and $5 \% \mathrm{CO}_{2}$. The cells were washed twice in PBS and stained with peridinin chlorophyll protein (PerCP)-conjugated anti-mouse cluster of differentiation (CD)80, fluorescein isothiocyanate-conjugated anti-mouse CD86 and phycoerythrin-conjugated anti-mouse MHC II (BD Biosciences, Franklin Lakes, NJ, USA) for $30 \mathrm{~min}$ on ice. Analysis was performed using a FACSCalibur flow cytometer in conjunction with CellQuest ${ }^{\mathrm{TM}}$ Pro software, version 6.0 (BD Biosciences). The expression levels of CD80, CD86 and MHC II in the BMDCs were defined as the mean fluorescence intensity.

Isolation of human PBMCs and stimulation with $\mathrm{CpG-HH2}$ formulations. The PBMCs were prepared by density gradient centrifugation of venous blood samples collected from healthy volunteers, as previously reported (11). Briefly, a volume of venous blood was centrifuged at $300 \mathrm{x} g$ at room temperature for $20 \mathrm{~min}$. The buffy coat was collected and diluted in 2-3 times volumes of complete RPMI 1640 medium. Following mixing, the mixture was layered on an equal volume $(5 \mathrm{ml})$ of Ficoll-Hypaque Plus (Tianjin Haoyang Biological Manufacture Co., Ltd., Tianjin, China). Following centrifugation at $400 \mathrm{x} \mathrm{g}$ at room temperature for $30 \mathrm{~min}$, the layer containing the PBMC fraction was obtained and suspended in RPMI 1640 (Invitrogen; Thermo Fisher Scientific, Inc.) at a cell concentration of $1 \times 10^{6}$ cells $/ \mathrm{ml}$. The PBMCs $\left(5 \times 10^{5}\right)$ were then seeded into 24-well tissue culture dishes and incubated for $1 \mathrm{~h}$ at $37^{\circ} \mathrm{C}$ in $5 \% \mathrm{CO}_{2}$. Subsequently, the PBMCs were stimulated with the CpG-HH2 formulations; ranging between 4:1 and 1:4 (wt/wt; with $\mathrm{CpG}$ ODN constant at $10 \mu \mathrm{g}$ ) for $24 \mathrm{~h}$ at $37^{\circ} \mathrm{C}$. All experiments were repeated on at least three separate occasions.

Chemokine/cytokine induction. Following $24 \mathrm{~h}$ culture with the $\mathrm{CpG}-\mathrm{HH} 2$ formulations, the culture supernatants were collected, and the concentrations of monocyte chemotactic protein (MCP)-1, IFN- $\gamma$ and TNF- $\alpha$ were detected using Quantikine ${ }^{\circledR}$ Huma MCP-1, IFN- $\gamma$, IL-4, IL-6 and TNF- $\alpha$ ELISA kits (R\&D Systems, Inc., Minneapolis, MN, USA), according to the manufacturer's protocol. Briefly, the culture supernatants were diluted 2-fold in assay diluent, and $100 \mu \mathrm{l}$ sample was added to each well and incubated at room temperature for $2 \mathrm{~h}$. Wells were washed with wash buffer (400 $\mu \mathrm{l})$ for a total of 5 times, and the antibodies against human MCP-1 conjugated to horseradish peroxidase (or the antibodies against human IFN- $\gamma$, IL-4, IL-6, TNF- $\alpha$; $100 \mu$ l) were added to each well followed by a $2 \mathrm{~h}$ incubation at room temperature. Wells were washed and incubated with $100 \mu 1$ substrate solution added for $30 \mathrm{~min}$ at room temperature. The reaction was allowed to develop for $30 \mathrm{~min}$, and absorbance was read as optical density (OD) at $450 \mathrm{~nm}$ using a Multiskan Mk3 (Thermo Fisher Scientific, Inc.). Values were corrected for background cytokine secretion by subtracting the concentrations in the control (medium) wells. The concentration of the cytokines in the culture medium was quantified by establishing a standard curve with serial dilutions of recombinant human MCP-1 (or recombinant human IFN- $\gamma$, IL-4, IL-6, TNF- $\alpha$ ).

Immunization of mice. Female C57BL/6J mice (6-8 weeks old) were purchased from the Experimental Animal Center of Sichuan University (Sichuan, China) and were maintained at
$23 \pm 1^{\circ} \mathrm{C}$ in a 12-h light/dark cycle with free access to food and water in the animal research facility. Groups $(n=5)$ of the female C57BL/6J mice were immunized by intramuscular injection of either 0.1 or $1 \mu \mathrm{g}$ HBsAg in combination with $25 \mu \mathrm{g}$ alum and/or $20 \mu \mathrm{g} \mathrm{CpG} \mathrm{ODN} \mathrm{(5'-TCGTCGTTTTGTCGTTTTGTC}$ GTT-3') and/or $40 \mu \mathrm{g}$ IDR-HH2 (VQLRIRVAVIRA-NH2) in a total volume of $100 \mu \mathrm{l}$ on weeks 0,2 and 4 . The mice were administered with a boost vaccine at the same dose at week 31 post-immunization. Blood $(50 \mu \mathrm{l})$ was collected from the mice via a retro-orbital puncture at $0,1,3,5,7,9,13,17,21,25$, 30, 32, 34, 50, 68 and 76 weeks. Subsequently, blood collected from the mice was clotted for $30 \mathrm{~min}$ in an incubator at $37^{\circ} \mathrm{C}$, and centrifuged at $2000 \mathrm{x}$ g for $10 \mathrm{~min}$ at $4^{\circ} \mathrm{C}$. Serum was transferred to the new tube, and stored at $-80^{\circ} \mathrm{C}$.

Evaluation of anti-HBsAg titer. HBsAg specific total IgG, IgG1, IgG2a, IgG2b and IgG3 immune responses were determined using end-point ELISA. In brief, NUNC Maxisorp ${ }^{\mathrm{TM}}$ plates (Thermo Fisher Scientific, Inc.) were coated with $0.1 \mu \mathrm{g} /$ well HBsAg in $0.05 \mathrm{M}$ sodium bicarbonate $(\mathrm{pH} 9.6$ ) overnight at $4^{\circ} \mathrm{C}$. Plates were washed, blocked and then incubated for $1 \mathrm{~h}$ at $37^{\circ} \mathrm{C}$ with two-fold serially diluted sera. Specific total IgG antibodies were detected using horseradish peroxidase (HRP)-conjugated goat anti-mouse IgG (1:5000; cat no. ZB-2305; ZSGB-BIO, Beijing, China). IgG sub-types were detected using HRP-conjugated goat anti-Mouse IgG1, IgG2a, IgG2b and IgG3 (1:400; cat nos. 5300-05; Southern Biotechnology, Inc., Birmingham, AL, USA; ), followed by the addition of substrate solution and incubated for $30 \mathrm{~min}$ at room temperature. OD was measured using a Multiskan Mk3 plate reader (Thermo Fisher Scientific, Inc.) The end-point dilution titers for the total $\mathrm{IgG}$ and IgG isotypes in the plasma were defined as the highest plasma dilution at an absorbance of $\mathrm{OD}_{450}$, which was double that of non-immune plasma, with a cut-off value of 0.05 . Seroconversion was defined as a dilution titer $\geq 100$.

IFN- $\gamma$ and IL-4 ELIspot assay. The spleens were removed from the mice 5 weeks following immunization with $\mathrm{HBs} \mathrm{Ag}$ with alum and/or CpG ODN and/or IDR-HH2 (n=3/group). Single splenocytes were obtained from the spleens using Ficoll-Hypaque PLUS (EZ-Sep Mouse 1x; Dakewei Biotech Co., Ltd., Shenzhen, China), and suspended in RPMI 1640 with $10 \%$ heat-inactivated FBS at a concentration of $5 \times 10^{6}$ cells $/ \mathrm{ml}$. The IFN- $\gamma$ and IL-4ELISpot assays were assessed using a mouse IFN- $\gamma /$ IL-4 kit (R\&D systems, Inc.), according to the manufacturer's protocol. The splenocytes were added to triplicate wells at a concentration of $5 \times 10^{5}$ cells/well, and were cultured in the presence of $10 \mathrm{mg} / \mathrm{ml} \mathrm{HBsAg}$ and the $\mathrm{HBsAg}$-derived peptides $\left(\mathrm{S}_{208-216}\right.$ and $\left.\mathrm{S}_{126-138}\right)$ or medium for $48 \mathrm{~h}$ at $37^{\circ} \mathrm{C}$. The stained spots were counted using a computer-assisted ELISpot image analyzer (CTL-ImmunoSpot S5; Cellular Technology, Ltd., Cleveland, OH, USA).

Assays for lymphocyte proliferation. The HBsAg-specific lymphoproliferative responses were assayed in the immunized mice (1 $\mu \mathrm{g}$ dose groups), as described previously (20). Briefly, the mice spleens were removed 5 weeks following immunization to produce single-cell suspensions for the assay. The splenocytes $\left(2 \times 10^{6}\right.$ cells $\left./ \mathrm{ml}\right)$ were suspended in complete 
RPMI 1640 with 5\% heat-inactivated FBS, and were added in triplicate to each well of 96-well round-bottom plates in a total volume of $100 \mu \mathrm{l}$. Subsequently, HBsAg was added at a concentration of $3 \mu \mathrm{g} / \mathrm{ml}$; and bovine serum albumin $(30 \mu \mathrm{g} / \mathrm{ml}$; Sigma-Aldrich) served as a negative control. Following 4 days in culture at $37^{\circ} \mathrm{C}$, the cells were pulsed with $\left[{ }^{3} \mathrm{H}\right]$ thymidine $(0.5 \mu \mathrm{Ci} /$ well) for $18 \mathrm{~h}$, washed twice in phosphate-buffered saline (PBS) and harvested for measurement of the incorporated radioactivity on a Topcount Microplate Scintillation and Luminescence Counter (Packard; Perkin Elmer, Inc., Waltham, MA, USA). The stimulation index was calculated based on the mean counts per minute (cpm) of the stimulated wells divided by the mean cpm of the control wells.

Statistical analysis. All experiments were performed on groups of 3-5 individual mice. Statistical comparisons were made with SPSS software, version 16.0.2 (SPSS, Inc., Chicago, IL, USA) using a one-way analysis of variance followed by Tukey's test. $\mathrm{P}<0.05$ was considered to indicate a statistically significant difference.

\section{Results}

IDR-HH2 induces chemotactic migration of THP-1 cells, RAW264.7cells and neutrophils. IDR peptides are potent immunoregulatory agents that, in conjunction with the innate and adaptive immune response, are capable of activating immune cells, inducing the production of cytokines and chemokines, and selectively modulating immune-mediated inflammation $(11,21)$. A previous study demonstrated that IDR-HH2 induces the migration of human neutrophils (12). In the present study, IDR-HH2 was chemotactic for the THP-1 and RAW264.7 cells in addition to the neutrophils (Fig. 1A-C). The migration of these cell types was observed to be typically bell-shaped and dose-dependent. The optimal chemotactic dose for the THP-1 cells and the neutrophils was $5 \mu \mathrm{g} / \mathrm{ml}$, whereas $10 \mu \mathrm{g} / \mathrm{ml}$ was the optimal dose for the RAW264.7 cells. To evaluate whether the combination of the CpG ODN formulation with IDR-HH2 enhanced chemotactic activity, complexes of increasing concentrations of $\mathrm{CpG}$ ODN (2.5-40 $\mu \mathrm{g} / \mathrm{ml})$ with $10 \mu \mathrm{g} / \mathrm{ml}$ IDR-HH2 $(10 \mu \mathrm{g} / \mathrm{ml})$ were assessed in these three cells. No significant increases in the number of migrated cells were observed, compared with the group administered with IDR-HH2 only in the chemotaxis assays (data not shown).

CpG-HH2 complex induces increased activation of BMDCs. To investigate the effects of the $\mathrm{CpG}-\mathrm{HH} 2$ complex on the phenotypical changes of BMDCs, immature BMDCs were stimulated in vitro with either CpG ODN $(5 \mu \mathrm{g} / \mathrm{ml})$ or IDR-HH2 $(10 \mu \mathrm{g} / \mathrm{ml})$, or with the formulated $\mathrm{CpG}-\mathrm{HH} 2$ complex for $16 \mathrm{~h}$. The ratio of $\mathrm{CpG}: \mathrm{HH} 2$ (wt/wt) was $1: 2$, as reported previously (11). LPS $(1 \mu \mathrm{g} / \mathrm{ml})$ served as a positive control. The cells were analyzed for the surface expression of MHC class II and costimulatory molecules, including CD80 and CD86. Stimulation of the BMDCs with IDR-HH2 resulted in a significant upregulation of CD80, compared with the cells incubated with CpG ODN (Fig. 2A). Enhanced expression of CD80 was induced by the $\mathrm{CpG}-\mathrm{HH} 2$ complex, although the difference was not significant, compared with IDR-HH2 alone. As shown in Fig. 2B, all the vaccination groups $(\mathrm{CpG}$ ODN, IDR-HH2, CpG-HH2 complex and LPS) induced high expression levels of CD86. As with CD80, stimulation with IDR-HH2 also resulted in a significant upregulation of $\mathrm{MHC}$ class II, compared with the cells incubated with $\mathrm{CpG}$ ODN (Fig. 2C), and MHC class II was induced by the $\mathrm{CpG}-\mathrm{HH} 2$ complex, although the difference was not significant, compared with IDR-HH2 alone. These data suggested that the $\mathrm{CpG}-\mathrm{HH} 2$ complex may be a potent stimulation agent promoting the maturation of BMDCs.

Synergistic effect of the CpG-HH2 complex on the production of chemokines and cytokines. Chemokines, potent chemoattractants of inflammatory cells, are critical in innate immunity (22). MCP-1, a member of the CC chemokine family, is widely used as a chemotactic and activating factor for monocytes or macrophages (23). In the present study, $\mathrm{CpG}$ ODN and IDR-HH2 were pre-complexed with serial dilutions of CpG:HH2 (wt/wt; 4:1-1:4, with CpG ODN at $10 \mu \mathrm{g}$ ) prior to simulation of the PBMCs. As shown in Fig. 3A, the marked induction in the expression of MCP-1 ex vivo exhibited an increasing trend with increasing concentration of the IDR-HH2 peptide. As cytokines are important in the development of the immune response, the concentrations of certain cytokines induced by the complexes, including TNF- $\alpha$, IFN- $\gamma$, IL-6 and IL-4, were measured using ELISA. The induction in the expression of IFN- $\gamma$ was similar to that of MCP-1, which was dose-dependent with concentration of IDR-HH2 (Fig. 3B). However, the enhanced induction of TNF- $\alpha$ was maximal at a 1:2 ratio of $\mathrm{CpG}: \mathrm{HH} 2$ among the four ratios (Fig. 3C). The concentrations of IL-4 and IL- 6 induced by the complexes were so low that they were undected (data not shown). When a compound is used as a vaccine adjuvant, its safety as well as potency requires demonstration. A previous study determined that $\mathrm{CpG}-\mathrm{HH} 2$ complexes have almost no cytotoxic properties (11). In the present study, the 1:2 (wt/wt) ratio of CpG:HH2 was used to examine its adjuvant effect for HBsAg.

Al-CpG-HH2 induces earlier and increased seroconversion. To further investigate the adjuvant effect of the $\mathrm{CpG}-\mathrm{HH} 2$ complex in vivo, mice were immunized with different doses of HBsAg $(1 \mu \mathrm{g}$ or $0.1 \mu \mathrm{g})$ combined with $\mathrm{Al}, \mathrm{Al}-\mathrm{CpG}$ or $\mathrm{Al}-\mathrm{CpG}-\mathrm{HH} 2$. The seroconversion and anti-HBs titer were detected using ELISA. When $0.1 \mu \mathrm{g} \mathrm{HBsAg}$ was administered with the adjuvant, no seroconversion was observed in any of the three experimental groups after 1 week. (Fig. 4A). However, the rate of seroconversion (titer $\geq 100$ ) in the Al-CpG-HH2 group (80\%) was $20 \%$ higher than in the Al-CpG group (60\%) at 1 week when the mice were immunized with $1 \mu \mathrm{g} \mathrm{HBsAg}$ (Fig. 4B). All vaccines were immunogenic in $100 \%$ of the mice immunized with $1 \mu \mathrm{g}$ of HBsAg at 3 and 5 weeks (Fig. 4B). However, when the mice were immunized with $0.1 \mu \mathrm{g} \mathrm{HBsAg}$, the rate of seroconversion in the $\mathrm{Al}-\mathrm{CpG}-\mathrm{HH} 2$ group at 3 weeks was $100 \%$, which was 60 and $80 \%$ higher than in the Al-CpG and Al groups, respectively (Fig. 4A). All samples successfully seroconverted at 5 weeks following immunization.

Al-CpG-HH2 triggers a robust and long-term HBsAg-specific antibody response. The humoral immune responses evoked by 
A

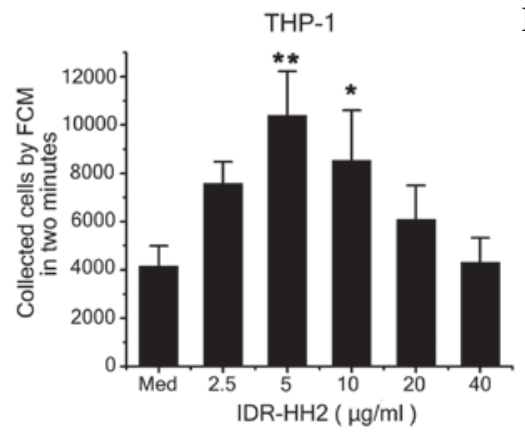

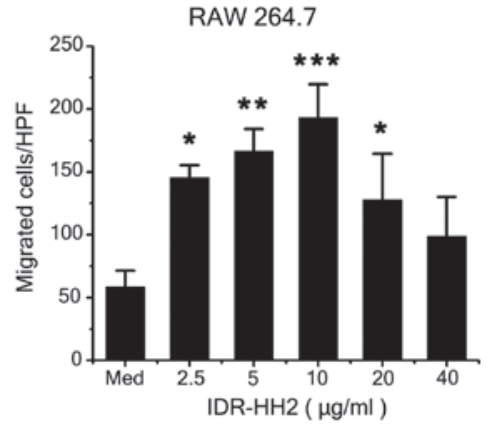

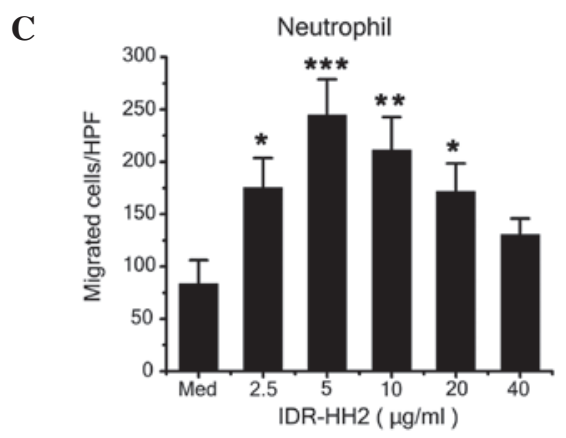

Figure 1. Effect of IDR-HH2 on the chemotactic migration of THP-1 cells, RAW264.7 cells and neutrophils. THP-1 cells $\left(2 \times 10^{5}\right)$, RAW264.7 cells $\left(5 \times 10^{5}\right)$ and neutrophils $\left(5 \times 10^{6}\right)$ were placed in the upper wells of a chemotactic microchamber, and $600 \mu 1$ of media containing differing concentrations of IDR-HH2 $(0-40 \mu \mathrm{g} / \mathrm{ml})$ was added to the lower wells. Folllowing incubation at $37^{\circ} \mathrm{C}$ for 45,90 and 180 mins, chemotaxis was assessed. Results of the migration of (A) THP-1 cells, (B) RAW264.7 cells and (C) neutrophils are presented. Values were compared with unstimulated cells, in medium (Med) alone). Data are expressed as the mean \pm standard deviation of three separate experiments. ${ }^{*} \mathrm{P}<0.05,{ }^{* * *} \mathrm{P}<0.01$ and ${ }^{* * * *} \mathrm{P}<0.001$, vs. Med. IDR, innate defense regulator; FCM, flow cytometry; HPF, high-power field.

A

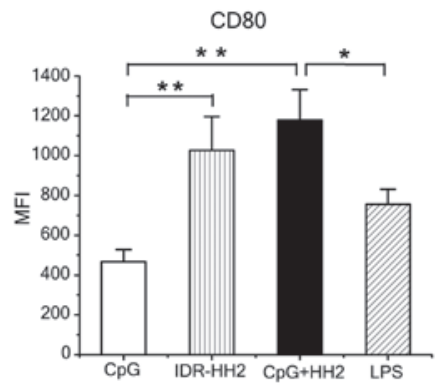

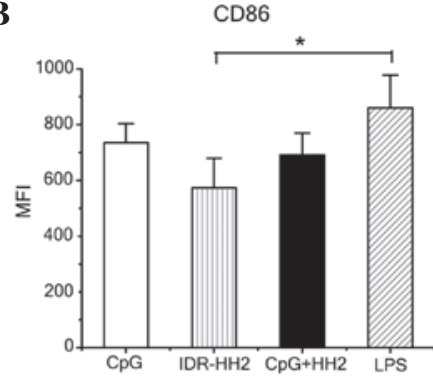

C MHC II

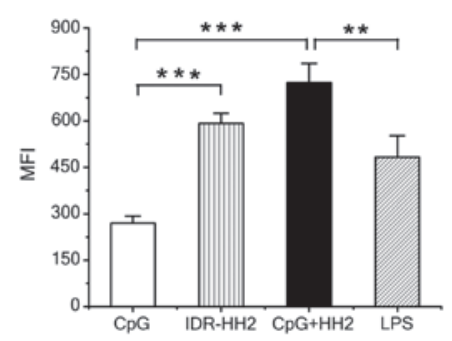

Figure 2. BMDCs stimulated with the $\mathrm{CpG}-\mathrm{HH} 2$ complex exhibit increased expression levels of CD80 and MHC II. BMDCs were incubated with CpG ODN, IDR-HH2, CpG-HH2 complex or LPS for $16 \mathrm{~h}$ and harvested. The expression levels of CD80, CD86 and MHC class II molecules were examined using flow cytometry. The levels of surface marker, defined as the MFI, were determined for. (A) CD80; (B) CD86 and (C) MHC II. Data are expressed as the mean \pm standard deviation of three separate experiments. ${ }^{*} \mathrm{P}<0.05,{ }^{* *} \mathrm{P}<0.01$ and ${ }^{* * * *} \mathrm{P}<0.001$. MFI, mean fluorescence intensity. BMDCs, bone marrow dendritic cells; IDR, innate defense regulator; LPS, lipopolysaccharide; $\mathrm{CD}$, cluster of differentiation; MHC, major histocompatibility complex.

each of the vaccine formulations were detected by measuring the HBsAg-specific serum IgG titers. In all groups, the peak antibody titers occurred 7 weeks following immunization. When the mice were administered with $0.1 \mu \mathrm{g} \mathrm{HBsAg}$, the
anti-HBs titers in the Al-CpG-HH2 group were significantly higher than those in the $\mathrm{Al}$ and $\mathrm{Al}-\mathrm{CpG}$ groups between weeks 5 and 25 post-immunization (Fig. 5A). When the dose of HBsAg was increased to $1 \mu \mathrm{g}$, the anti-HBs titers of the 

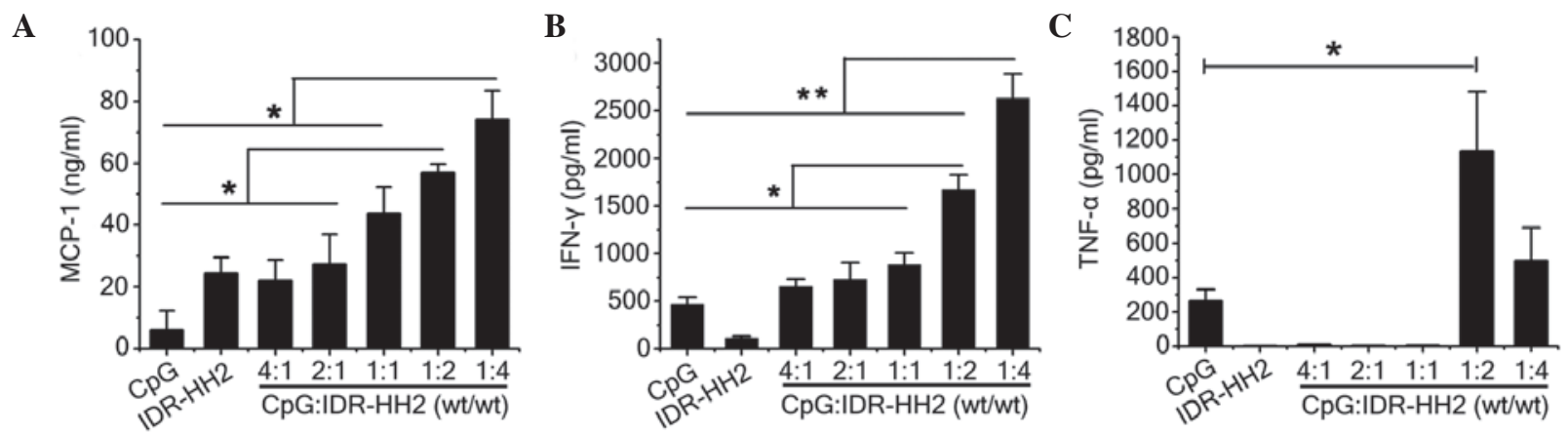

Figure 3. Cytokine and chemokine secretions by PBMCs are stimulated by the CpG-HH2 complex in vitro. PBMCs were prepared and stimulated with the CpG-HH2 formulations ( wt/wt; 4:1-1:4) for $24 \mathrm{~h}$. The culture supernatants were collected and the secretions of (A) MCP-1, (B) IFN- $\gamma$ and (C) TNF- $\alpha$ were detected using ELISA. Data are expressed as the mean \pm standard deviation of three independent experiments. ${ }^{*} \mathrm{P}<0.05$ and ${ }^{* *} \mathrm{P}<0.01$. PMBCs, peripheral blood mononuclear cells; MCP-1, monocyte chemotactic protein 1 ; IFN- $\gamma$, interferon; TNF- $\alpha$, tumor necrosis factor; IDR, innate defense regulator.

A

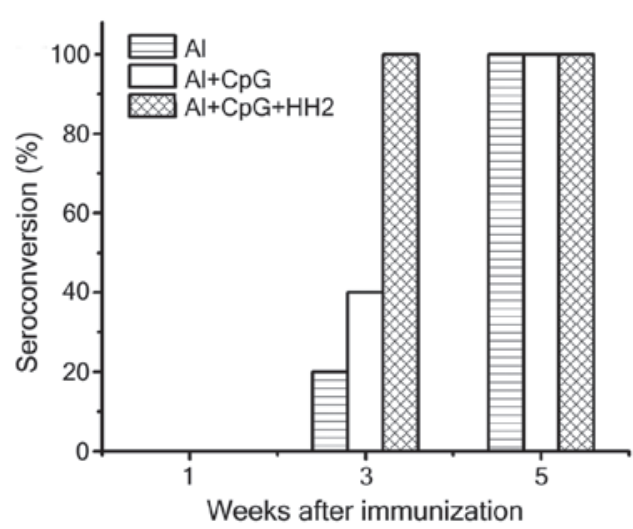

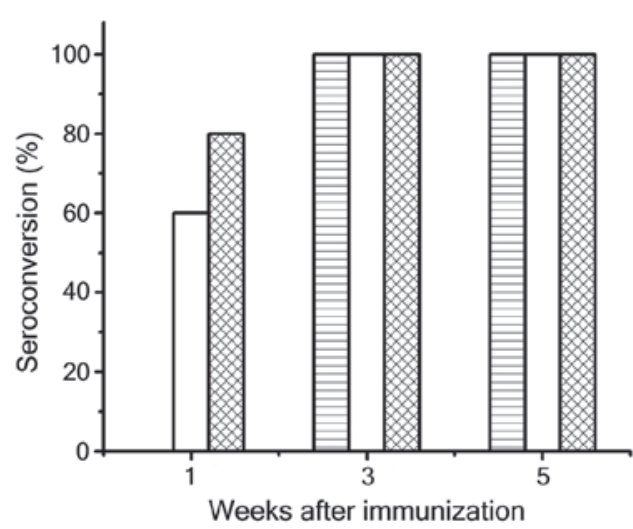

Figure 4. CpG-HH2 complex produces higher seroconversion. Mice were immunized with $\mathrm{HBs}$ Ag in combination with Al, Al-CpG or Al-CpG-HH2 at $0,2,4$ weeks. Sera obtained at 1, 3, 5 weeks was assayed for anti-HBs by endpoint-dilution ELISA. Seroconversion was defined as a dilution titer $\geq 100$. (A) Seroconversion of mice immunized with $0.1 \mu \mathrm{g}$ HBsAg with the various adjuvants. (B) Seroconversion of mice immunized with $1 \mu \mathrm{g}$ HBsAg with the various adjuvants. Al, alum; HBsAg, hepatitis B surface antigen.

Al-CpG-HH2 group were also enhanced, compared with those in the $\mathrm{Al}$ and $\mathrm{Al}-\mathrm{CpG}$ groups (Fig. 5B). Although the titers decreased between weeks 21 and 30 post-immunization, the levels of HBsAg-specific antibodies in the mice immunized with the Al-CpG-HH2 vaccine remained higher than those in the mice immunized with the Al vaccine. Following administration of the mice with the same dose of vaccines at week 31 , the anti-HBs titers in the Al-CpG-HH2 group were marginally higher than, or similar to, those of the Al-CpG group, but were markedly higher than those of the $\mathrm{Al}$ group (Fig. 5A and B). These results indicated that both groups of Al-CpG-HH2 and $\mathrm{Al}-\mathrm{CpG}$ triggered potent immune responses, which may have the same effects in memory recall. Of note, the anti-HBs titers elicited by the Al-CpG-HH2 complex and $0.1 \mathrm{mg}$ of HBsAg were markedly higher than those evoked by alum with $1 \mathrm{mg} \mathrm{HBsAg}$ (Fig. 5A).

Al-CpG-HH2 induces a balanced Th1/Th2 immune response. To evaluate the type of Th response evoked by the vaccine, anti-HBs antibody isotypes (IgG1, IgG2a, IgG2b and IgG3) were detected 7 weeks post-immunization using ELISA (Fig. 6A and B). Alum produced a clear Th2 response with a predominantly $\operatorname{IgG1}$ titer, regardless if it was administered with $0.1 \mu \mathrm{g}$ (Fig. 6A) or $1 \mu \mathrm{g}$ (Fig. 6B) HBsAg. When CpG
ODN was administered with alum, the combination evoked a Th1-biased response, with a more marked improvement in the IgG2a titer. Finally, the CpG-HH2 complex suspended in alum provided a balanced Th1/Th2 response, with similar improvements in the IgG1 and IgG2a titers, as the ratios of IgG2a/IgG1 in the mice immunized with 0.1 and $1 \mu \mathrm{g}$ HBsAg were 1 and 0.8 , respectively (data not shown).

To further characterize the immune response induced by each of the formulations, the production of IL-4/IFN- $\gamma$ by $\mathrm{HBs} A g$-exposed splenocytes from immunized mice was examined using ELISpot following re-stimulation of splenocytes with $\mathrm{HBsAg}$ and epitopes $\mathrm{HBsAg}_{208-216}$ and $\mathrm{HBsAg}_{126-138}$ epitopes. Following re-stimulation with $\mathrm{HBsAg}$, significantly higher numbers of IL-4-secreting cells and IFN- $\gamma$-secreting cells were found in the mice of the Al-CpG-HH2 group, compared with the Al-CpG group $(\mathrm{P}<0.01)$. In addition, the number of IFN- $\gamma$-secreting cells was marginally higher than the number of IL-4-secreting cells in the Al-CpG-HH2 group (Fig. 6C). Furthermore, immunization with a combination of HBsAg and Al-CpG-HH2 significantly increased IFN- $\gamma$ secretion in response to the $\mathrm{HBsAg}_{208-216}$ and $\mathrm{HBsAg}_{126-138}$ peptides (Fig. 6D), suggesting that the co-formulation of HBsAg with Al-CpG-HH2 induced a balanced Th1/Th2 immune response to HBsAg, which was MHC class I- and II-restricted. These 
A

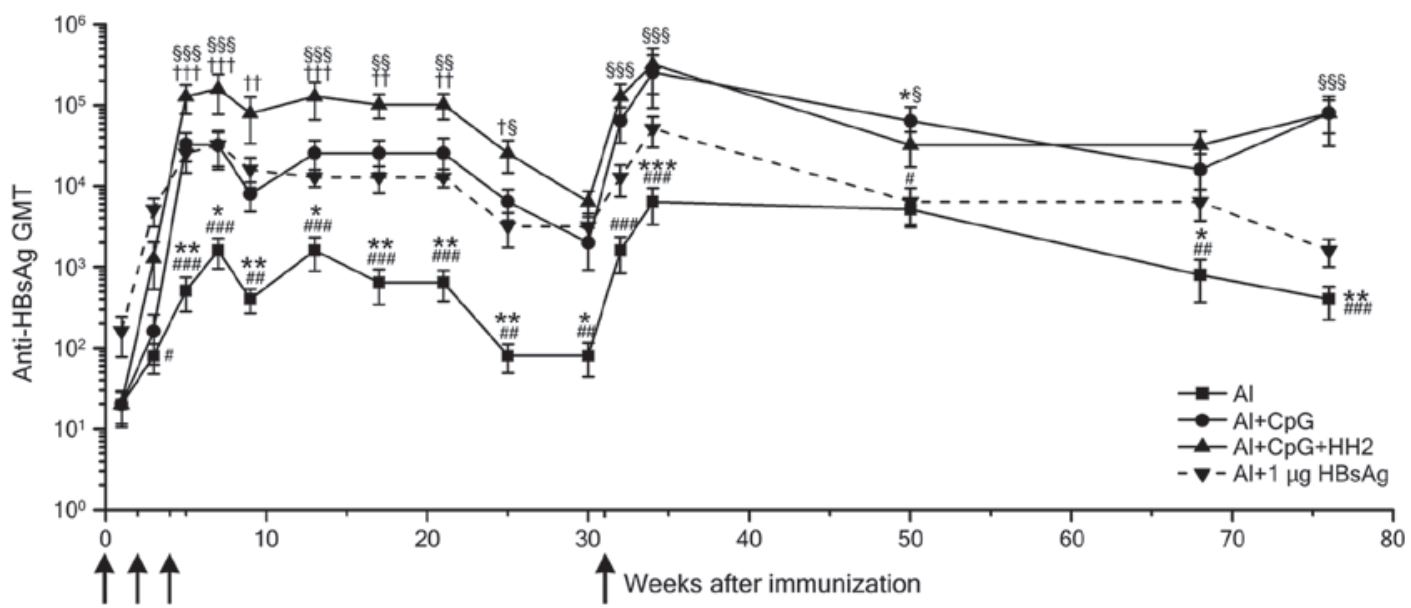

B

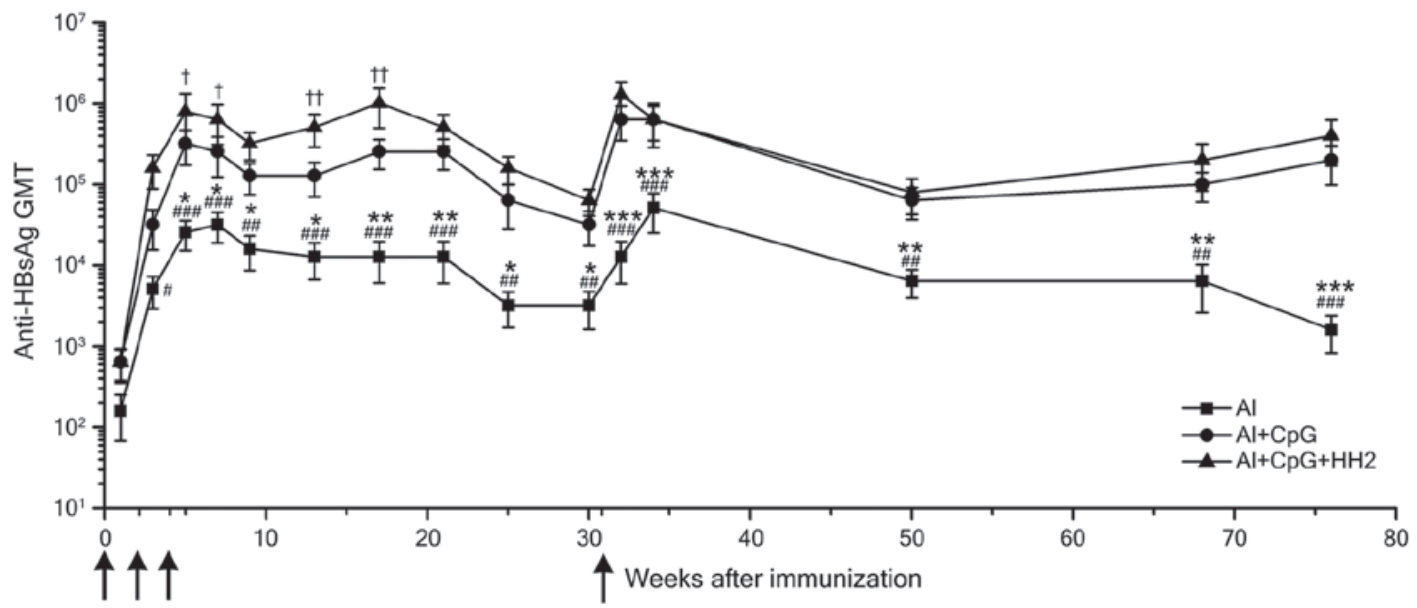

Figure 5. HBsAg-specific antibody responses in mice immunized with $\mathrm{HBsAg}$ and the $\mathrm{Al}, \mathrm{Al}-\mathrm{CpG}$ or $\mathrm{Al}-\mathrm{CpG}-\mathrm{HH} 2$ adjuvant. C57BL/6J mice were immunized three times intramuscularly with HBsAg $(0.1$ or $1 \mu \mathrm{g})$ formulated with $\mathrm{Al}\left(25 \mu \mathrm{g} \mathrm{Al}{ }^{3+}\right)$, Al-CpG (20 $\left.\mu \mathrm{g}\right)$ or Al-CpG-HH2 $(40 \mu \mathrm{g})$ at $0,2,4$ weeks (black arrow). To detect the memory immune response, the mice were boosted with the same HBV vaccine as for their primary immunization at 31 weeks. (A) Anti-HBs titer kinetics of mice immunized with $0.1 \mu \mathrm{g} \mathrm{HBsAg}$ with the various adjuvants (black solid line) and $1 \mathrm{mg}$ of $\mathrm{HBsAg}$ with Al (dotted line). (B) Anti-HBs titer kinetics of mice immunized with $1 \mu \mathrm{g}$ HBsAg with the various adjuvants. Data are expressed as the mean \pm standard deviation in the group (n=5) titers, as determined using ELISA. ${ }^{*} \mathrm{P}<0.05,{ }^{* *} \mathrm{P}<0.01$ and ${ }^{* * *} \mathrm{P}<0.001$, Al group vs. $\mathrm{Al}+\mathrm{CpG}$ group; ${ }^{*} \mathrm{P}<0.05,{ }^{\# \#} \mathrm{P}<0.01$ and ${ }^{\# \# \#} \mathrm{P}<0.001, \mathrm{Al}$ group vs. Al+CpG+HH2 group; ${ }^{\dagger} \mathrm{P}<0.05,{ }^{\dagger} \mathrm{P}<0.01$ and ${ }^{+} \mathrm{P}<0.001, \mathrm{Al}+\mathrm{CpG}+\mathrm{HH} 2$ group vs. $\mathrm{Al}+\mathrm{CpG}$ group; ${ }^{\circledR} \mathrm{P}<0.05,{ }^{\S} \mathrm{P}<0.01$ and ${ }^{\S}{ }^{\S} \mathrm{P}<0.001, \mathrm{Al}+\mathrm{CpG}+\mathrm{HH} 2$ group vs. $\mathrm{Al}+1 \mu \mathrm{g} H B s \mathrm{Hg}$ group. $\mathrm{Al}$, alum; HBsAg, hepatitis B surface antigen; HBV, hepatitis B virus; GMT, geometric mean titer.

results suggested that the co-formulation of HBsAg with alum and the CpG-HH2 complex induced significant increases in the antibody- and cell-mediated immune responses.

Al-CpG-HH2 enhances the T cell proliferative response. To further evaluate the vaccine enhancing effects on T cells, a $\mathrm{T}$ cell proliferative response assay was evaluated, as previously described (20). Groups of C57BL/6J mice were administered with intramuscular injections of normal saline, or with a mixture of $\mathrm{HBsAg}$ with alum, $\mathrm{Al}-\mathrm{CpG}$, or Al-CpG-HH2. At 5 weeks post-immunization, the splenocytes of the mice were examined for proliferation in response to specific (HBsAg) and nonspecific (BSA) stimulation. The mice immunized with the Al-CpG-HH2 vaccine developed a significant $\mathrm{T}$ cell-proliferative response to $\mathrm{HBsAg}$, but not to the control BSA protein. Compared with the $\mathrm{Al}$ and $\mathrm{Al}-\mathrm{CpG}$ groups, immunization with Al-CpG-HH2 resulted in significant $(\mathrm{P}<0.05)$ cellular proliferation, with an average peak stimulation index of 5.4 (Fig. 6E). The mice of the $\mathrm{Al}$ and $\mathrm{Al}-\mathrm{CpG}$ groups exhibited a markedly lower T cell-proliferative response to $\mathrm{HBsAg}$, with average peak stimulation indices of 2.3 and 2.7, respectively (Fig. 6E). The failure of all the mice in the various groups to respond to the negative protein BSA (even at $30 \mu \mathrm{g} / \mathrm{ml}$ ) indicated that the $\mathrm{T}$ cell-proliferative responses were specific for $\mathrm{HBsAg}$.

\section{Discussion}

Vaccines consisting of subunit or protein antigens are often poorly immunogenic, compared with traditional vaccines (24), and, therefore, require approaches to improve their immunogenicity. Strategies, which can enhance the immunogenicity predominantly focus on two factors, the antigen and the adjuvant. For the antigen, previous studies have demonstrated that using overlapping peptides (prS1 or prS2) with mammalian cell-produced HBsAg can overcome immune non-responsiveness (25). However, the expense of mammalian-produced antigens limits its clinical application. Another study demonstrated that prS1 or prS2 peptide vaccines evoked a potent $\mathrm{T}$ cell-mediated immune response when supplied with more antigen (26). Owing to the use of 
A

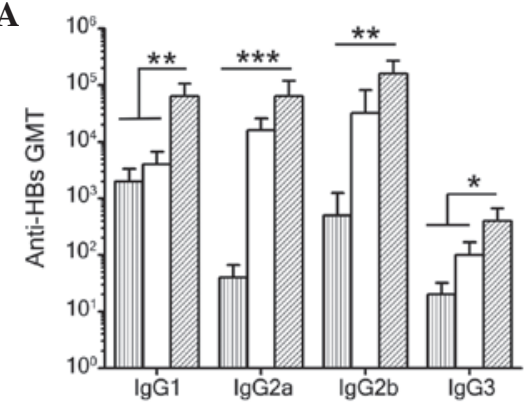

C

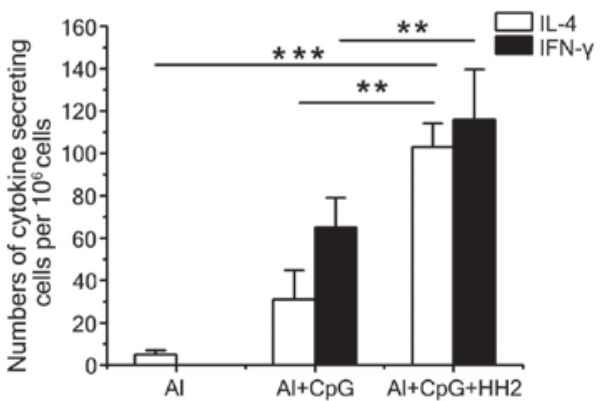

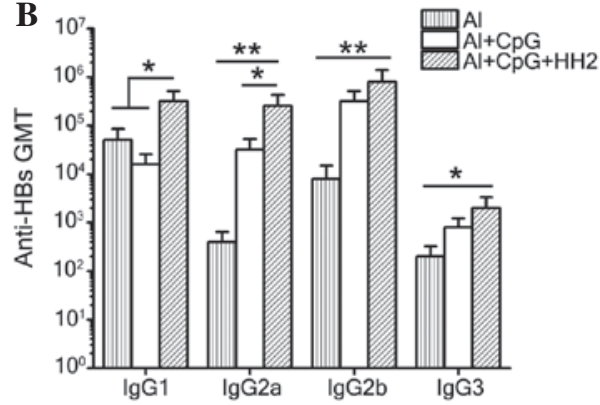

D

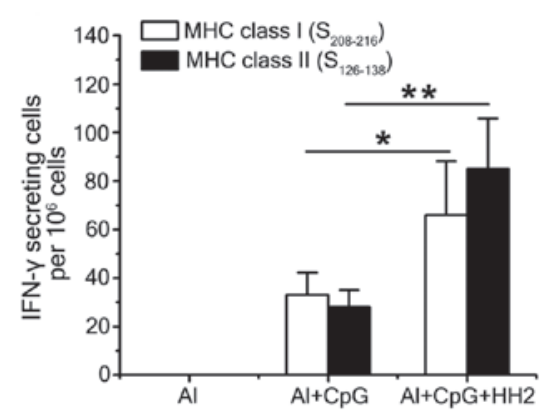

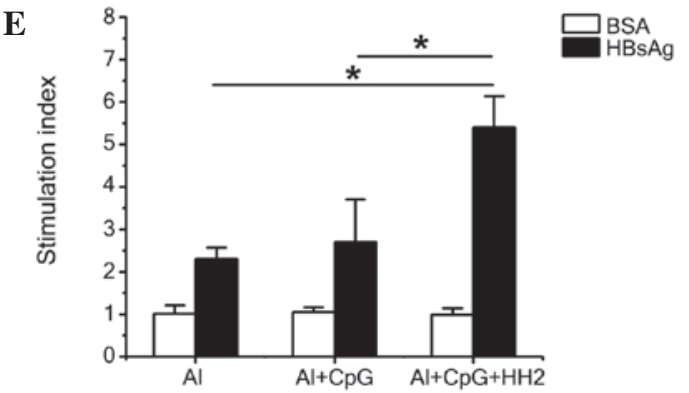

Figure 6. CpG-HH2 evokes a balanced Th1/Th2 immune response. Antibody isotypes in C57BL/6J mice 7 week following immunization with (A) $0.1 \mu \mathrm{g}$ $\mathrm{HBsAg}$ or (B) $1 \mu \mathrm{g} \mathrm{HBsAg}$ and $\mathrm{Al}, \mathrm{Al}-\mathrm{CpG}$ or Al-CpG-HH2. Data are expressed as the mean \pm standard deviation of the group (n=5) titers, as determined using ELISA. (C and D) Groups of C57BL/6J mice were immunized intramuscularly with $1 \mathrm{mg} \mathrm{HBsAg}$ and either Al, Al-CpG or Al-CpG-HH2 at 0, 2 , 4 weeks. Splenocytes were obtained 5 week following immunization, followed by re-stimulation with (C) $10 \mu \mathrm{g} / \mathrm{ml} \mathrm{HBsAg}$ or the (D) $\mathrm{HBsAg}$-derived peptides, $S_{208-216}$ and $S_{126-138}$. The numbers of cytokine-secreting cells were detected using an ELISpot assay. (E) T-cell proliferation assays. Splenocytes were prepared, as described above and re-stimulated with HBsAg and BSA at final concentrations of $10 \mu \mathrm{g} / \mathrm{ml}$ and $30 \mu \mathrm{g} / \mathrm{ml}$, respectively. Data are presented as the mean \pm standard deviation. ${ }^{*} \mathrm{P}<0.05,{ }^{* *} \mathrm{P}<0.01$ and ${ }^{* * *} \mathrm{P}<0.001$. HBsAg, hepatitis B surface antigen; Th, $\mathrm{T}$ helper; AL, alum; BSA, bovine serum albumin; Ig, immunoglobulin; GMT, geometric mean titer; IL, interleukin; IFN, interferon; MHC, major histocompatibility complex.

a high doses of antigen, this approach is limited by the reactivity, leading to more side effects. However, in the present study, when the HBsAg dose was decreased between 1 and $0.1 \mathrm{mg}$, the Al-CpG-HH2 complex maintained its effects of earlier seroconversion and higher anti-HBs titer, compared with the $\mathrm{Al}$ or $\mathrm{Al}-\mathrm{CpG}$ treatments (Figs. 4 and 5). In particular, combination of the Al-CpG-HH2 complex with $0.1 \mathrm{mg}$ of HBsAg induced a more marked anti-HBs immune response, compared with that induced by $\mathrm{Al}$ with $1 \mathrm{mg}$ of HBsAg in the experimental period, after the first 3 weeks (Fig. 5A).

The investigation of novel adjuvants, essential components of vaccines, has become a crucial method in improving the immunogenicity of antigens. Alum, the only adjuvant approved by the Food and Drug Administration, has become the standard adjuvant for use in humans, and been used in a large number of immunization regimens (27). Alum is traditionally considered to form a long-lasting depot for antigens to promote their uptake by antigen-presenting cells (APCs), resulting in the induction of a Th2 immune response with fewer cytotoxic T lymphocyes (28). The present study confirmed that alum evoked a Th2 immune response, with predominant IL-4 production being detected using ELIspot (Fig. 6C) and poor T-cell proliferation activity (Fig. 6E).

Human host defense peptides are key in linking innate and adoptive immunity (29), therefore, they are typically used as vaccine adjuvants. Examples include cathelicidin (LL-37), human neutrophil peptide (HNP)1-3 and human $\beta$-defensin (30-33). The immunomodulatory activities of these peptides include the chemoattraction of macrophages and $\mathrm{T}$ lymphocytes, and the induction of dendritic cell maturation (34). Such peptides are often long or complex, limiting their synthesis and use in manufacturing. IDR-HH2, a short novel host defense peptide synthetic mimic, was designed and investigated by Kindrachuk et al (11), who suggested that IDR-HH2 is a potential immune modulating peptide. In the present study, it was first demonstrated that IDR-HH2 was chemotactic for monocytes (THP-1) and macrophages (RAW264.7) in addition to neutrophils (Fig. 1A-C). These 
innate immune cells migrated to the injection site of vaccine immunization, in addition to phagocytizing and presenting antigens to APCs through the secretion of various cytokines, enhancing the innate immune response.

The novel CpG ODN adjuvant induces an immunomodulatory cascade that involves B and T cells, natural killer cells and APCs (15,35). CpG ODN induces a Th1-type immune response, producing IL-12 and IFN- $\gamma$ (36). Preclinical and ongoing investigations indicate that $\mathrm{CpG}$ ODN is effective and safe for use as an adjuvant in various vaccines (37). The combination of alum and $\mathrm{CpG}$ ODN used as an adjuvant for HBV vaccines evoked a Th1 immune response in one study (38). Another study found that alum-CpG in an HBV vaccine induced a mixed Th1/Th2 (Th0) response in young mice (39). In the present study, Al-CpG produced a mixed Th1-type immune response to HBsAg, as demonstrated by a higher IgG2a titer (Fig. 6A and $\mathrm{B}$ ) and the predominant production of IFN- $\gamma$, according to the ELIspot assay (Fig. 6C). The adjuvant combination induced more marked humoral- and cell-mediated immune responses, compared with those evoked by alum alone, as indicted by the higher anti-HBs titer and increased production of IFN- $\gamma$. Previous studies have suggested the use of CpG-HH2 complex as a potential vaccine adjuvant due to its ability to upregulate immature DCs and enhance antibody titers, and its low associated cytoxicity (11). Consistent with these findings, the present study demonstrated that the peptide IDR-HH2 exerted effective immunomodulatory activity when used as in complex with CpG-HH2, but not alone.

The present study used the CpG-HH2 complex as an adjuvant in a commercial HBV vaccine. The results indicated that the $\mathrm{CpG}-\mathrm{HH} 2$ complex significantly increased the secretion of chemokines and cytokines, including MCP-1, TNF- $\alpha$ and IFN- $\gamma$ in vitro (Fig. 3). Its adjuvant effects with the HBV vaccine were then assessed in vivo, and the combination of the $\mathrm{CpG}-\mathrm{HH} 2$ complex with alum resulted in earlier seroconversion and higher anti-HBs titers, compared with those in the control groups (Figs. 4 and 5). Notably, the combination induced marked anti-HBs immune responses when the dose of HBsAg was decreased between 1 and $0.1 \mu \mathrm{g}$, and immunization of this complex with a low dose of HBsAg $(0.1 \mu \mathrm{g})$ elicited higher antibody titers, compared with those evoked by alum with a high dose ( $1 \mu \mathrm{g})$ of HBsAg (Fig. 5A). These findings suggested that the Al-CpG-HH2 complex may enable a reduction in the levels of antigen in the $\mathrm{HBV}$ vaccine, without compromising its adjuvant effect, resulting in a decrease in the cost and risk associated with administration of $\mathrm{HBV}$ vaccines.

Previous studies have indicated that hyporesponsive and unresponsive individuals fail to respond to HBV vaccines, primarily due to a defect in the production of primary HBsAg-specific T cells or functional defective B cells (40-44). In the present study, the antibody isotypes and ELIspot assay suggested that the Al-CpG-HH2 complex induced a balanced Th1/Th2 immune response. The cell-medicated immune response induced by the Al-CpG-HH2 complex and $\mathrm{HBsAg}$ may be key in clearing HBV infections. Furthermore, the T-cell proliferation indicated the potential application of this adjuvant to overcome non-responsiveness to HBsAg.

In conclusion, the present study demonstrated that Al-CpG-HH2 may be used as a novel adjuvant for HBV vaccines, as it enhanced humoral immunity and cell-mediated immune responses in $\mathrm{C} 57 / \mathrm{BL}$ mice. Therefore, this complex may reduce the dose of $\mathrm{HBsAg}$ in $\mathrm{HBV}$ vaccines, resulting in a decrease in manufacturing costs and increases in vaccine safety, with applications in unresponsive individuals, including those with perinatal infection. According to the results presented, it is suggested that the combination of the $\mathrm{CpG}-\mathrm{HH} 2$ complex with alum may be a novel and effective adjuvant.

\section{Acknowledgements}

The study was supported by the National Major Scientific and Technological Special Project for 'Significant New Drugs Development' (grant. no. 2013ZX09102030) and the Foundation for Sichuan Distinguished Young Academic and Technology Leaders (grant. no. 2012JQ0014).

\section{References}

1. Reed SG, Orr MT and Fox CB: Key roles of adjuvants in modern vaccines. Nat Med 19: 1597-1608, 2013.

2. Mutwiri G, Gerdts V, van Drunen Littel-van den Hurk S, Auray G, Eng N, Garlapati S, Babiuk LA and Potter A: Combination adjuvants: The next generation of adjuvants? Expert Rev Vaccines 10: 95-107, 2011.

3. Aebig JA, Mullen GE, Dobrescu G, Rausch K, Lambert L, Ajose-Popoola O, Long CA, Saul A and Miles AP: Formulation of vaccines containing $\mathrm{CpG}$ oligonucleotides and alum. J Immunol Methods 323: 139-146, 2007.

4. Kovacs-Nolan J, Latimer L, Landi A, Jenssen H, Hancock RE, Babiuk LA and van Drunen Littel-van den Hurk S: The novel adjuvant combination of $\mathrm{CpG}$ ODN, indolicidin and polyphosphazene induces potent antibody- and cell-mediated immune responses in mice. Vaccine 27: 2055-2064, 2009.

5. Cao D, Li H, Jiang Z, Xu C, Cheng Q, Yang Z, Cao G and Zhang L: Synthetic innate defence regulator peptide enhances in vivo immunostimulatory effects of $\mathrm{CpG}-\mathrm{ODN}$ in newborn piglets. Vaccine 28: 6006-6013, 2010.

6. Weeratna RD, Brazolot Millan CL, McCluskie MJ and Davis HL: CpG ODN can re-direct the Th bias of established Th2 immune responses in adult and young mice. FEMS Immunol Med Microbiol 32: 65-71, 2001.

7. Thaker HD, Som A, Ayaz F, Lui D, Pan W, Scott RW, Anguita J and Tew GN: Synthetic mimics of antimicrobial peptides with immunomodulatory responses. J Am Chem Soc 134: 11088-11091, 2012.

8. Hancock RE and Sahl HG: Antimicrobial and host-defense peptides as new anti-infective therapeutic strategies. Nat Biotechnol 24: 1551-1557, 2006.

9. Li M, Shi H, Mu Y, Luo Z, Zhang H, Wan Y, Zhang D, Lu L, Men K, Tian Y, et al: Effective inhibition of melanoma tumorigenesis and growth via a new complex vaccine based on NY-ESO-1-alum-polysaccharide-HH2. Mol Cancer 13: 179, 2014.

10. Wu X, Wang Z, Li X, Fan Y, He G, Wan Y, Yu C, Tang J, Li M, Zhang $X$, et al: In vitro and in vivo activities of antimicrobial peptides developed using an amino acid-based activity prediction method. Antimicrob Agents Chemother 58: 5342-5349, 2014.

11. Kindrachuk J, Jenssen H, Elliott M, Townsend R, Nijnik A, Lee SF, Gerdts V, Babiuk LA, Halperin SA and Hancock RE: A novel vaccine adjuvant comprised of a synthetic innate defence regulator peptide and $\mathrm{CpG}$ oligonucleotide links innate and adaptive immunity. Vaccine 27: 4662-4671, 2009.

12. Niyonsaba F, Madera L, Afacan N, Okumura K, Ogawa H and Hancock RE: The innate defense regulator peptides IDR-HH2, IDR-1002 and IDR-1018 modulate human neutrophil functions. J Leukoc Biol 94: 159-170, 2013.

13. Klinman DM: CpG DNA as a vaccine adjuvant. Expert Rev Vaccines 2: 305-315, 2003.

14. Nierkens S, den Brok MH, Garcia Z, Togher S, Wagenaars J, Wassink M, Boon L, Ruers TJ, Figdor CG, Schoenberger SP, et al: Immune adjuvant efficacy of $\mathrm{CpG}$ oligonucleotide in cancer treatment is founded specifically upon TLR9 function in plasmacytoid dendritic cells. Cancer Res 71: 6428-6437, 2011. 
15. Cooper CL, Davis HL, Morris ML, Efler SM, Adhami MA, Krieg AM, Cameron DW and Heathcote J: CPG 7909, an immunostimulatory TLR9 agonist oligodeoxynucleotide, as adjuvant to Engerix-B HBV vaccine in healthy adults: A double-blind phase I/II study. J Clin Immunol 24: 693-701, 2004.

16. Lee CC, Avalos AM and Ploegh HL: Accessory molecules for Toll-like receptors and their function. Nat Rev Immunol 12: 168-179, 2012.

17. Mendez S, Tabbara K, Belkaid Y, Bertholet S, Verthelyi D, Klinman D, Seder RA and Sacks DL: Coinjection with CpG-containing immunostimulatory oligodeoxynucleotides reduces the pathogenicity of a live vaccine against cutaneous Leishmaniasis but maintains its potency and durability. Infect Immun 71: 5121-5129, 2003.

18. Brown TH, David J, Acosta-Ramirez E, Moore JM, Lee S, Zhong G, Hancock RE, Xing Z, Halperin SA and Wang J.: Comparison of immune responses and protective efficacy of intranasal prime-boost immunization regimens using adenovirus-based and $\mathrm{CpG} / \mathrm{HH} 2$ adjuvanted-subunit vaccines against genital Chlamydia muridarum infection. Vaccine 30 350-360, 2012.

19. Kumar S, Jones TR, Oakley MS, Zheng H, Kuppusamy SP, Taye A, Krieg AM, Stowers AW, Kaslow DC and Hoffman SL: CpG oligodeoxynucleotide and Montanide ISA 51 adjuvant combination enhanced the protective efficacy of a subunit malaria vaccine. Infect Immun 72: 949-957, 2004.

20. Chow YH, Chiang BL, Lee YL, Chi WK, Lin WC, Chen YT and Tao MH: Development of Th1 and Th2 populations and the nature of immune responses to hepatitis B virus DNA vaccines can be modulated by codelivery of various cytokine genes. J Immunol 160: 1320-1329, 1998.

21. Scott MG, Dullaghan E, Mookherjee N, Glavas N, Waldbrook M, Thompson A, Wang A, Lee K, Doria S, Hamill P, et al: An anti-infective peptide that selectively modulates the innate immune response. Nat Biotechnol 25: 465-472, 2007.

22. Ishida T, Oyama T, Carbone DP and Gabrilovich DI: Defective function of Langerhans cells in tumor-bearing animals is the result of defective maturation from hemopoietic progenitors. J Immunol 161: 4842-4851, 1998.

23. Mackay CR: Chemokines: Immunology's high impact factors. Nat Immunol 2: 95-101, 2001.

24. Billeskov R, Elvang TT, Andersen PL and Dietrich J: The HyVac4 subunit vaccine efficiently boosts BCG-primed anti-mycobacterial protective immunity. PLoS One 7: e39909, 2012.

25. Milich DR, Thornton GB, Neurath AR, Kent SB, Michel ML, Tiollais P and Chisari FV: Enhanced immunogenicity of the pre-S region of hepatitis B surface antigen. Science 228 $1195-1199,1985$

26. Liljeqvist $S$ and Stahl S: Production of recombinant subunit vaccines: Protein immunogens, live delivery systems and nucleic acid vaccines. J Biotechnol 73: 1-33, 1999.

27. Flach TL, Ng G, Hari A, Desrosiers MD, Zhang P, Ward SM, Seamone ME, Vilaysane A, Mucsi AD, Fong Y, et al: Alum interaction with dendritic cell membrane lipids is essential for its adjuvanticity. Nat Med 17: 479-487, 2011.

28. Fritz JH, Brunner S, Birnstiel ML, Buschle M, Gabain Av, Mattner $F$ and Zauner W: The artificial antimicrobial peptide KLKLLLLLKLK induces predominantly a TH2-type immune response to co-injected antigens. Vaccine 22: 3274-3284, 2004.
29. Huang W, Seo J, Willingham SB, Czyzewski AM, Gonzalgo ML, Weissman IL and Barron AE: Learning from host-defense peptides: Cationic, amphipathic peptoids with potent anticancer activity. PLoS One 9: e90397, 2014.

30. Ren SX, Cheng AS, To KF, Tong JH, Li MS, Shen J, Wong CC, Zhang L, Chan RL, Wang XJ, et al: Host immune defense peptide LL-37 activates caspase-independent apoptosis and suppresses colon cancer. Cancer Res 72: 6512-6523, 2012

31. Hurtado P and Peh CA: LL-37 promotes rapid sensing of $\mathrm{CpG}$ oligodeoxynucleotides by B lymphocytes and plasmacytoid dendritic cells. J Immunol 184: 1425-1435, 2010.

32. Soehnlein O, Kai-Larsen Y, Frithiof R, Sorensen OE, Kenne E, Scharffetter-Kochanek K, Eriksson EE, Herwald H, Agerberth B and Lindbom L: Neutrophil primary granule proteins HBP and HNP1-3 boost bacterial phagocytosis by human and murine macrophages. J Clin Invest 118: 3491-3502, 2008.

33. Hilchie AL, Wuerth K and Hancock RE: Immune modulation by multifaceted cationic host defense (antimicrobial) peptides. Nat Chem Biol 9: 761-768, 2013.

34. Harder J, Bartels J, Christophers E and Schröder JM: A peptide antibiotic from human skin. Nature 387: 861, 1997.

35. Bode C, Zhao G, Steinhagen F, Kinjo T and Klinman DM: CpG DNA as a vaccine adjuvant. Expert Rev Vaccines 10: 499-511, 2011.

36. Klinman DM, Yi AK, Beaucage SL, Conover J and Krieg AM: $\mathrm{CpG}$ motifs present in bacteria DNA rapidly induce lymphocytes to secrete interleukin 6, interleukin 12 and interferon gamma. Proc Natl Acad Sci USA 93: 2879-2883, 1996.

37. Klinman DM: Immunotherapeutic uses of $\mathrm{CpG}$ oligodeoxynucleotides. Nat Rev Immunol 4: 249-258, 2004.

38. Weeratna RD, McCluskie MJ, Xu Y and Davis HL: CpG DNA induces stronger immune responses with less toxicity than other adjuvants. Vaccine 18: 1755-1762, 2000.

39. Brazolot Millan CL, Weeratna R, Krieg AM, Siegrist CA and Davis HL: CpG DNA can induce strong Th1 humoral and cell-mediated immune responses against hepatitis B surface antigen in young mice. Proc Natl Acad Sci USA 95: 15553-15558, 1998.

40. Chedid MG, Deulofeut H, Yunis DE, Lara-Marquez ML, Salazar M, Deulofeut R, Awdeh Z, Alper CA and Yunis EJ: Defect in Th1-like cells of nonresponders to hepatitis B vaccine. Hum Immunol 58: 42-51, 1997.

41. Larsen CE, Xu J, Lee S, Dubey DP, Uko G, Yunis EJ and Alper CA: Complex cytokine responses to hepatitis B surface antigen and tetanus toxoid in responders, nonresponders and subjects naive to hepatitis B surface antigen. Vaccine 18: 3021-3030, 2000

42. Goncalves L, Albarran B, Salmen S, Borges L, Fields H, Montes H, Soyano A, Diaz Y and Berrueta L: The nonresponse to hepatitis B vaccination is associated with impaired lymphocyte activation. Virology 326: 20-28, 2004.

43. Chiou SS, Yamauchi K, Nakanishi T and Obata H: Nature of immunological non-responsiveness to hepatitis $\mathrm{B}$ vaccine in healthy individuals. Immunology 64: 545-550, 1988.

44. Shokrgozar MA and Shokri F: Enumeration of hepatitis B surface antigen-specific B lymphocytes in responder and non-responder normal individuals vaccinated with recombinant hepatitis $B$ surface antigen. Immunology 104: 75-79, 2001. 